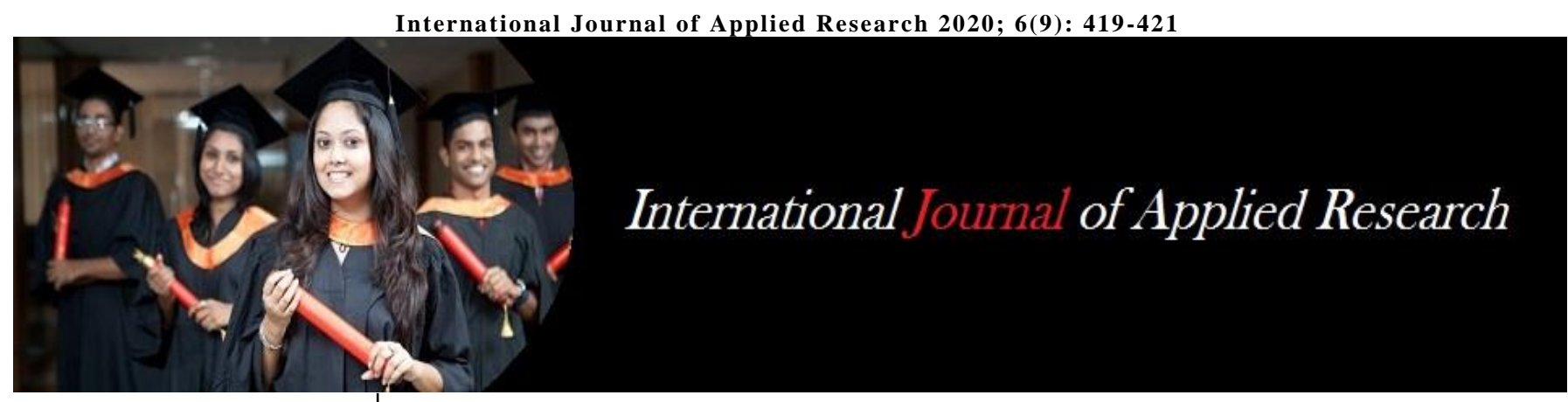

ISSN Print: 2394-7500

ISSN Online: 2394-5869

Impact Factor: 5.2

IJAR 2020; 6(9): 419-421

www.allresearchjournal.com

Received: 18-06-2020

Accepted: 16-08-2020

Suresh Sharma

Chaudhary Charan Singh

University, Meerut,

Uttar Pradesh, India
Corresponding Author:

Suresh Sharma

Chaudhary Charan Singh

University, Meerut,

Uttar Pradesh, India

\section{School of contemporary jurisprudence}

\section{Suresh Sharma}

DOI: $\underline{\text { https://doi.org/10.22271/allresearch.2020.v6.i9f.7185 }}$

\section{Abstract}

School of Contemporary Jurisprudence as India's indigenous Jurisprudence shall be sufficient for Indian Democratic and Judiciary requirements and Effect of upcoming Contemporary Jurisprudence upon Mankind.

Keywords: Contemporary jurisprudence, school of jurisprudence

\section{Introduction}

It's primary requirement of Mankind for maintaining civilization, whereas modern civilization depend on democratic and judicial system, whereas Jurisprudence is supreme source of democracy and judiciary. Worldwide all democratic structures, constitutions and Judiciary systems have been grown up from the roots of jurisprudence. Therefore, Jurisprudence is the actual soul of every democratic and judicial system.

Whereas ours democratic systems, constitutions and Judiciary systems are products of Natural, Analytical, Historical, Sociology and Realistic School of Jurisprudence, which contributed by various jurists of U.K., Germany, France and America etc. Whenever school of natural Jurisprudence is consider under primitive Jurisprudence and others are Analytical, Historical, Sociology and Realistic School of Jurisprudence are consider as part of Modern Jurisprudence.

\section{Analysis of Primitive Jurisprudence}

Natural school of Jurisprudence has been developed by pioneered jurists as Aristotle, Socrates and Hindu Vedic, which are more emphasis upon natural rights, which are predicted by nature to every person equally. The period between B.C. 350 to 15th century is considering for primitive Jurisprudence.

\section{Analysis of Modern Jurisprudence}

The period since after 15 th century is considering for modern Jurisprudence.

Contribution of Analytical, Historical, Sociology, Realistic and Contemporary school of Jurisprudence to Mankind -

1. Analytical Jurisprudence or Imperative School (Austinian school) was propounded by Bentham and Austin (U.K). Austin is known as father of analytical school of Jurisprudence. Analytical Jurisprudence more emphasis upon what is law and what ought to be law. Analytical School of Jurisprudence awarded intellectual capability to Mankind to understand, what law is and how to understand the law.

2. Historical jurisprudence was propounded by Savigny (Germany). Savigny was more emphasis upon law is source of custom, ritual etc. Historical school of Jurisprudence awarded Mankind for customs are playing important role in law making process. Savigny is known as father of Historical Jurisprudence, whereas Montesquieu, Henry Maine and Puchta are other pioneer jurist of Historical Jurisprudence.

3. Sociology jurisprudence was more Emphasis upon social activity, like society, Government and others. This was first School of Jurisprudence, which more focus upon basic rights of public and interacted to judicial connection with public. Ihering, Roscoe Pound, August Comte, Ehrlich and Duguit are main jurists of Sociology school of 
Jurisprudence. Rudolph Van Inhering is known as Father of Sociology school of Jurisprudence. He tried for club the Analytical school with Sociology school of Jurisprudence.

4. Realistic jurisprudence was propounded by John Grey (America). This school of Jurisprudence more emphasis upon Court proceeding, judgement, role of judges. He predicted that "Judgements are the source of law". John Grey and Oliver Wendell Holmes are consider as Father of Realism school of Jurisprudence and Jeremy Frank and Levellyn are consider as other Pioneer jurists of Realism. Therefore, United Kingdom launched Analytical/Imperative school of jurisprudence (1800 to 1850), which was propounded by Bentham and Austin. Germany launched Historical School of Jurisprudence and Sociology School of Jurisprudence (1750 to 1890), likewise Friedrich Savigny and Ihering called as father of Historical Jurisprudence and Father of Sociology Jurisprudence respectively. USA launch realism school of jurisprudence, which was propounded by John Grey and Oliver Wendell Holmes during (1950-1920), likewise called as father of Realist Jurisprudence. Therefore, UK, Germany, France and USA are mostly recognizable states, for having intellectual capability of jurisprudence.

5. Contemporary jurisprudence propounded by Deepak Sharma (India) recently. Contemporary Jurisprudence more emphasis upon democracy and justice. The theory of contemporary Jurisprudence has been designed for targeting, how to empowered the democratic structure, and increase the efficiency and effectiveness of judicial systems. This is first School of Jurisprudence of $21^{\text {st }}$ century, this school of Jurisprudence awarded intellectual capability of three level democratic system and centralized judicial system to Mankind. Contemporary Jurisprudence is considering as 5th School of Modern Jurisprudence. Therefore, Deepak Sharma is called as father of Contemporary Jurisprudence. In the entire history of jurisprudence, Contemporary Jurisprudence denied present two level (The Public and Parliamentary) democratic system, on the ground that is personal interests of elected person are differs from Public Interest.

In same respect, Mr. Sharma propounded three level democratic structure (Society, Society representative and Parliament). He also propounded the 5 types of law segregation process, which could be done through by joint operations of parliamentary and society representative session, whereas Society means a group of people which having common interests and Society representative refers as an elected person of society, on other hand Parliament is as representative session of Public. Mr. Sharma also propounded the various others concept of jurisprudence as the Degree of democracy, types of law, developing stages of judicial system etc. Besides it, Contemporary Jurisprudence declined the Bar-Bench judicial system, on the ground of decentralized processing.

In same regard, Contemporary Jurisprudence advocates for the world's first centralized judicial system, by name as Just-in-trial system (J.I.T). Contemporary Jurisprudence claims for J.I.T, after implementation of J.I.T, Judicial system shall be 25 times faster and 20 times more transparent against Bar Bench judicial system. It is also a Surprise that Independent role of Bench (judges) has been denied by Contemporary Jurisprudence historically. In same matter, a new concept of Chartered law officer (a new judicial officer) has been introduced, whereby Chartered law officer has been designated as independent judicial person instead of Bench (judge).

\section{Conclusion}

1. Whether school of Contemporary Jurisprudence having separate philosophy from previous school of jurisprudence

Unlike previous School of Jurisprudence, School of Contemporary Jurisprudence do not follow any philosophy. Contemporary Jurisprudence more emphasis upon to build strong democratic system and to build judiciary system more effective, efficient and transparent.

School of Contemporary Jurisprudence has been discovered the answers of various questions, which are not covered by previous School of Jurisprudence, such as -

(a) How to develop a judiciary system for any state?

(b) What is relationship between democratic system and judiciary system?

(c) How many types of Laws exists globally?

(d) What is Degree of democracy, and impact of democracy on judicial system?

(e) How to empower the Democratic system.

(f) Any other alternative for Bar Bench Judicial System, in same respect Centralized Judiciary system (J.I.T) has been going to unveil.

I further state as aforesaid (a) to (f) are sufficient material to propound the new school of Jurisprudence. In same regard, I am on the point, Mankind is suffering from Poverty, Corruption, Crime and Prejudice justice etc. Therefore, instantly required more intellectual capabilities in the field of Jurisprudence, whereas School of Contemporary Jurisprudence could be capable for currently Judicial and Democratic requirements of Mankind.

\section{A comparison between Contemporary Jurisprudence} and previous school of jurisprudence

a) Unlike previous school of jurisprudence, Contemporary Jurisprudence do not show any philosophy, its more emphasis on conceptual bias, instead of any philosophy.

b) Contemporary jurisprudence has been developed to find out answer the basic question of jurisprudence, which are not covered by previous school of jurisprudence.

c) Contemporary jurisprudence more emphasize upon the efficiency and effectiveness of judicial system. Contemporary jurisprudence more emphasis/target's to solve all judicial and democratic requirement for mankind.

\section{Future impact of Contemporary Jurisprudence on Democracy}

By gone through Contemporary Jurisprudence, Mankind shall be capable or establishing next generation democratic structure. In a practical aspect, if present Two levels of Democratic Structure (Public - Parliament) replaced by Three Levels of Democratic Structure (Pubic, Parliament and Society representation) and It shall be a huge Democratic revolution in the History of Mankind. 


\section{Future impact of Contemporary Jurisprudence on Judicial system}

J.I.T (new centralized judicial system of Contemporary Jurisprudence) claims itself, as 25 times faster (efficient) and 20 times more transparent against current Bar-Bench Judicial system, in that case crime rate must be decrease, therefore Law and order shall be maintain more effective and efficient, this step shall be further milestone in the entire history of mankind.

\section{Contribution of Deepak sharma in Jurisprudence}

At current point of time, Mankind is suffering from various issue of civilization, which could be solved through gain the intellectual capability of Jurisprudence.

This is undoubted that Deepak Sharma play an important role in History of Jurisprudence, in meantime period, when Mankind instantly required the new democratic and judicial approach. He also propounded the various theory of jurisprudence, which more clarify the actual picture of Jurisprudence such as -

a. The issue upon, how to be an effective and efficient judicial system developed has been clarify through the theory of developing stage of Judicial System.

b. Mankind suffering from awarding delay in justice due to decentralized bias of Judicial System (Bar - Bench), aforesaid requirement of mankind seem to satisfied, in same regard centralized judicial trial process (J.I.T) has been invented.

c. That was a controversial issue upon types of law and there developing process, aforesaid Issue upon type of laws and law-making process has been more clarified.

d. Relationship of democracy with judiciary, theory of developing stage of judiciary stages, degree of democracy, types of law, Parliament-Public-Society relationship structure, and centralized trial process are new Jurisprudence concepts, which has been acknowledged for Mankind by Contemporary Jurisprudence.

The burden of proof to prove the Contemporary Jurisprudence, always be exists on shoulders of Mr. Deepak Sharma called as father of Contemporary Jurisprudence, and Mankind always be looking toward him for more details of Contemporary Jurisprudence.

\section{Future impact of Contemporary Jurisprudence on India as well as Mankind}

a. India as a Union of States along with many other Nations of world, are still dependent upon two level Democratic structure (Public and Parliamentary), while Contemporary Jurisprudence advocates for three level Democratic structure (Society, Society representative and Parliamentary) whereas Society representative shall be a session of elected person of various segments of public. No doubt, it shall be session of intellectual person, which shall be belongs to various interest field of Public. Therefore, intellectual capabilities for law making must be increased, on the other, hand Parliament shall be as representation of Public. Both Parliament and Society representative session shall be mandatory dependent to each other for law making process, on the other hand, Policy developing process for state welfare shall be more reliable and viable. Therefore, I am on the point, by going through the
Contemporary Jurisprudence the Democratic structure shall be empowered.

b. Contemporary Jurisprudence shall be capable to fulfil all judicial requirements of Mankind. Current period of time, India as well as various states of India are using British judicial system, which is based on Bar- Bench trial proceeding, whenever Bar-Bench is decentralized judicial proceed system, which is suitable for only states, which have population under 4-5 crore, while India as caring population more than 130 crores. Therefore current British judiciary system is not suitable for India, therefore world's first centralized judicial trial proceeding system called as Just-in-trial (J.I.T) has been invented, which shall be 25 times faster and 20 time more transparent against Bar-Bench judicial trial system. J.I.T shall be sufficient weapon for fulfil Indian judicial requirement, Whenever Contemporary Jurisprudence has been prove itself against cardinal principle of Jurisprudence, it is great opportunity for mankind as well as India, and it shall be enormous mile stone in the history of Jurisprudence and entire history of mankind.

\section{References}

1. https://english.newsnationtv.com/campaign/know-yourrights/india-to-attain-intellectual-capability-ofjudiciary-engineering-258906.html

2. https://www.patrika.com/noida-news/the-judicialsystem-will-be-25-times-faster-and-20-times-moretransparent-by-contemporary-judicial-science-6378754/ 